\title{
Chenchus and Social Transformation: A Study of a Primitive Tribe in Kurnool District of Andhra Pradesh
}

\author{
P.Subbarama Raju ${ }^{1}$, C. Sudhakar ${ }^{1}$ and Ch. Umamohan ${ }^{2}$ \\ 1. Department of Rural Development and Social Work, 2. Department of Sociology, \\ S.K.University, Anantapur, Andhra Pradesh, India
}

KEYWORDS Rehabilitation. Education. Employment. Festivals. Rituals. Recreation

\begin{abstract}
The Chenchus are one of the aboriginal tribes of Andhra Pradesh. They are mostly confined to foothills of low lying areas of Nallamalai hills of South India. This study has been carried out with reference to Chenchus of Kurnool district. The study brings out the process of social transformation of Chenchus on account of programmes of the Integrated Tribal Development Agency. The analysis has been presented with reference to Moity groups. The sample households are divided into three specific groups based on the Moity of the Chenchu households. It must be born in mind that changes and developments experienced by Chenchus under reference are within the overall context of the trends of change and development that have been taking place in the country during the past five decades.
\end{abstract}

\section{INTRODUCTION}

The Scheduled Tribes particularly the primitive tribes are placed in the most disadvantageous position in modern India. The backwardness of the tribe is attributed largely to their long isolation from the general society and their exploitation by the non-tribes. Tribals who have contributed to the richness of our culture and heritage have been neglected and isolated particularly during $19^{\text {th }}$ and early $20^{\text {th }}$ centuries.

India started her large scale planned development planning in 1951. This development planning derives its objectives and social premises from the 'Directive Principles of the State Policy' set forth in the Constitution of India. The objectives of our development plans are to initiate a process of all round balanced development which would ensure a rising national income and steady improvement in the living standards. Ironically the backlash of these efforts resulted in the suffering of some tribals in the form of displacement and prompted the evolution of planned efforts for tribal development and suitable policies for the protection of their rights. These efforts have initiated the process of social transformation among them. Therefore in the present paper an attempt is made to profile the changes in social and economic life in the context of a Primitive Tribe namely Chenchus, who are mostly spread in Kurnool district of Andhra Pradesh.

The population of Scheduled Tribes in India as per 1991 Census is 6.78 crores, which constitutes 8.02 per cent to the total population. There are about 427 tribes in India, subdivided into different groups (Roy Burman 1971). They speak over 105 languages and 225 different dialects. They are scattered along the length and breadth of Indian Ocean and from the Arabian Sea to the Eastern Frontiers.

Out of 427 identified tribal communities in India, thirty three tribal groups, who are at different stages of socio-economic development, are living in Andhra Pradesh State. Of the thirty three Scheduled Tribes of Andhra Pradesh eight tribal groups viz., Chenchus, Kolam, Kondareddy, Konda Savaras, Gadabas, Gonds, Porjas and Thotis have been recognized as primitive tribal groups by the Government of India. These eight tribes are extremely backward tribal groups who are identified as primitive tribal groups because they are at the pre-agricultural stage of economy characterized by low level of literacy and who largely depend on food gathering for their subsistence.

\section{THE CHENCHUS}

The Chenchu tribe was recognized as one of the primitive tribal groups in 1975 (GOI 1985-90). Not much is known about the history and origin of the tribe except for a very few references made about them by the administrators who were engaged in collecting monographic data on the tribes and castes of India (Bhowmik 1992). The Chenchus are listed as Scheduled Tribe in Andhra Pradesh under Scheduled Castes and 
Scheduled Tribes Lists Modifications Order, 1956. They are mostly found in the districts of Kurnool, Mahaboobnagar, Prakasam and Guntur of Andhra Pradesh. The Chenchus are mentioned in Manusmrithi (Chapter X.48). An ecological meaning is sought to be attributed to the word 'Chenchu' meaning "a person who lives under a chettu" (tree) (Ayyappan 1948).

The Chenchus are one of the aboriginal tribes of Andhra Pradesh. They are mostly confined to foothills and low lying areas of Amarbad Plateau and Nallamalai hills in Kurnool, Mahaboobnagar, Prakasam, Rangareddy, Nalgonda and Guntur districts respectively. The distribution of the Chenchu population is presented in Table 1 .

Table 1: Chenchu population district-wise (1991 Census )

\begin{tabular}{llr}
\hline S. No. & District & Population \\
\hline 1 & Mahaboobnagar & 5,979 \\
2 & Prakasam & 5,606 \\
3 & Kurnool & 4,845 \\
4 & Guntur & 5,407 \\
5 & Nalgonda & 780 \\
6 & Rangareddy & 1,691 \\
\hline & Total & 24,308 \\
\hline
\end{tabular}

Source: ITDA Abstract, 1994.

The distribution of Chenchu population among different revenue mandals of Kurnool district reveals that they are spread in 11 revenue mandals of the total 54 revenue mandals in Kurnool District. However, they are found in large numbers only in Atmakur (1,371), Kothapalli (834), Srisailam (514), and Panyam (422); and in small numbers ranging from 41 to 359 in other revenue mandals such as Allagadda, B.Atmakur, Velgodu, Mahanandi, Chagalamarri, Rudravaram and Pamulapadu.

Chenchus are an endogamous group with exogamous clans. Clans are the larger population divisions in the tribal. The existing social organization among the Chenchus is of Murdock's Dakota type, which is characterized by patrilineal descent type of cousin terminology (Thurston and Rangachari 1909).

According to the 1961 Census of India, 26 clans among the Chenchus are found in the three districts of Prakasam, Mahaboobnagar and Kurnool. They are: (1) Marrepalle, (2) Mandla, (3) Eravala, (4) Nimmala, (5) Chigurla, (6) Thokala, (7) Pulicherla, (8) Udutaluri, (9) Dasari, (10) Mayillu, (11) Kotrayu, (12) Balmuri, (13)
Kiannimunne, (14) Blumani, (15) Kudumula, (16) Garaboina, (17) Gulla, (18) Topi, (19) Arthi, (20) Bojja, (21) Mamidi, (22) Gaddamollu, (23) Pittollu, (24) Falli, (25) Chavadi, and (26) Nallapathulu (Reddy 1961). The above is only an illustrative list. This may vary from district to district or region to region or due to changes in their occupational or other cultural pursuits. For instance, in addition to the above, new clan groups like Uttaluru, Indla, Thota, Golla are being reported in the present study.

All the above clans do not exist among the Chenchus of Kurnool district. There is some confusion regarding the existence of larger exogamous divisions or phratries among the Chenchus. The Chenchus are not aware of any such division among them, but they have a notion that some clans are closer to one another between which marriage is prohibited.

The analysis has been presented with reference to Moity groups. The sample households are divided into three specific groups based on the Moities of the Chenchu households. The Moities of the respondent households have been ranked basing on the number of respondent households in each Moity of the Chenchus. The first Moity group consists of (1) Arathi, (2) Thota, and (3) Uttaluri Moities, which represent 20 or more households in each Moity.

The second Moity group consists of (1) Indla, (2) Nimmala, (3) Golla, (4) Tokala, (5) Mekala, (6) Savara, (7) Pulicherla each representing the number of households between 10 and 20 households. The third Moity group consists of (1) Kaki, (2) Puli, (3) Maliki, (4) Dasari, (5) Jampu, (6) Chigurla, (7) Kamineni, (8) Dommasani, (9) Bill, (10) Manipatti, (11) Chavadi, (12) Guljari, (13) Jalli, (14) Raya, (15) Ujani, (16) Kudumula, (17) Mazzali, (18) Salam, each representing less than 10 households. In order to assess the impact of developmental programmes of Chenchus, we need to understand the socio-economic characteristics of the Chenchus, as such an understanding helps to assess the impact of developmental programmes on Chenchus.

\section{Developmental Programmes and Social Transformation}

The Integrated Tribal Development Programme (I.T.D.A) adopted the area under study in the year 1975-76. To assess the impact of the developmental programmes of both I.T.D.A and 
other general developmental trends in the neighborhood, an attempt is made to examine such variables as education, child labour, and age at marriage, employment generation, and cultural transformation.

The two decades of developmental intervention by I.T.D.A. has ushered in perceptible and appreciable social transformation and change of life style among the Chenchus under study.

The rehabilitation of the Chenchus, who were formerly isolated primitive tribals, notorious for highway dacoity, was rather successfully accomplished by the ITDA. This is achieved by rehabilitating Chenchus. Rehabilitation of Chenchus in new settlement colonies which are provided with pucca housing and other amenities such as electricity and drinking water; school and the provision of alternate employment opportunities, allotment of agricultural land, bank loans these efforts enabled the Chenchus for the first time in centuries to lead a peaceful sedentary life. The practice of agriculture, agricultural labour, poultry, business, formal schooling brought them close to the main streams of population and facilitated greater social intervention. Thus the barriers of social isolation have been broken and ushered a change of life style.

The close contact and interaction with the officials, other neighbouring villagers, and the impact of schooling also had gradually led them to a greater social awareness and in particular awareness about their rights. In other words, the developmental interventions have led to a slow but steady process of social empowerment of Chenchus in the areas of education, marriage, employment, observance of festivals and rituals, and in their general life style.

Education: The I.T.D.A. and the general developmental programme are of a recent phenomenon for the last two decades. They have contributed to the increasing levels of literacy attainments among Chenchus of younger generation.

The rural folk by and large view the developmental process in a pragmatic view and the Chenchus under reference are no expectation to this. While the Chenchus appreciate the general significance of literacy and formal education, they do hold a skeptical view on the utility of literacy and formal school education in their day-to-day life and in particular its role in their vocational pursuits. As majority of them are engaged in unorganised/unskilled labour activities. According to them, the formal schooling and literacy attainments do not help them achieve fuller employment opportunities in these sectors. Yet the efforts of ITDA in promoting schooling are encouraging.

Our study reveals that the attainment of literacy levels among the younger Chenchus is significant $\left(\chi^{2}=156.04\right.$ at 0.05 levels $)$. This is particularly true with regard to young Chenchus between the age group of 6-14 years. Of the 194 members in this group only 34 are illiterate and non-school going (14.91 per cent) (Table 2). Further it is observed that Tribal Ashram schools have contributed a lot to attaining literacy levels among Chenchus.

Marriage: The Chenchus are experiencing a change in the observance of their rituals particularly with reference to the practice of marriage. Traditionally, marriage by elopement or marriage by abduction was the common practices of marriage among Chenchus. Divorces, widow marriages, remarriage were also common. Today the Chenchus slowly prefer the arranged marriages. The frequency of elopements and abduction are gradually declining on account of their sedentary life style. However, the practice of divorce, re-marriage and widow marriage are still continuing. There is not much change in the observance of other rituals like, funeral rites, birth and many such other ceremonies.

Age at Marriage: Before the launch of ITDA the age at marriage of Chenchu Man was higher due to their nomadic life, poor subsistence (Table 3 ). Now there is significant change in this practice. Our analysis reveals that on account of developmental programmes, Chenchu men are getting married at a lower age than before as they are now leading sedentary life, and are hopeful of employment if they are educated and are assured of subsistence due to government sponsored public distribution of rations at subsidized rates. The lower age at marriage among Chenchus who were born after the launch of I.T.D.A. programme is found to be significant (Male $\chi^{2} 0.05=10.49$, Female $\chi^{2} 0.05=7.9$ ).

Employment: It is observed that unemployment and underemployment looms large among the Chenchus under study. Chenchus who are involved in service and petty business activities alone are able to get employment for 365 and 275 days respectively in a year. A great majority of Chenchus (79.85 per cent) are unemployed for greater part of the year. 


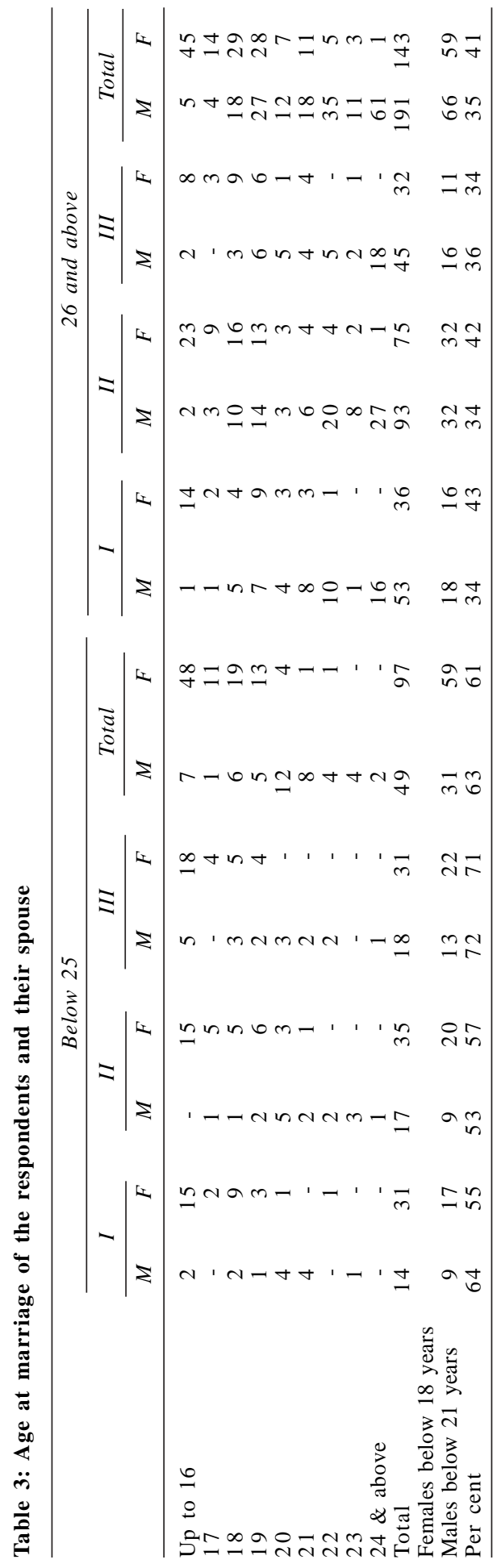

Notwithstanding the general scenario of underemployment and unemployment, it is found that on account of I.T.D.A. activities a small percentage (13.58 per cent) of Chenchus were able to get full-time employment in different services, and a few could depend on petty business activities. A large percentage (57.84 per cent) of Chenchus could bank on minor forest produce collection on account of I.T.D.A. intervention and due to Girijan co-operatives for the marketing.

The developmental programmes created more employment to the tribal people who availed themselves of the programme. Therefore it is assumed that the benefited households should have more employment at present than before. This can be measured with the help of number of mandays of employment available to the respondent households. The mandays of employment has increased after availing benefits from the developmental programmes in the case of all Moity groups, but it is higher among the Third Moity group (26 per cent) than first and second Moity groups (17 per cent). The tribal people normally depend on forest for their employment. The government has been trying to provide alternative employment opportunities through the ITDA by distributing agriculture land to the landless people, providing financial assistance for goat rearing, dairying, mat weaving and other items of developmental programmes. Therefore, the tribal people have been depending both on forest and on developmental programmes for their full-time employment.

Festivals: The Chenchus due to their interaction with the plains, have gradually absorbed some of the "great traditions" in the form of observing festivals like Deepavali, Sankranthi, and Vinayaka Chowthi etc. They also continue their "little traditions".

Recreation: A visible transition is seen in the recreation practices of Chenchus. The Chenchus who were once entertaining themselves with folk traditions are now gradually shifting to modern means of entertainment such as watching TV, Cinema etc. The practice of group drinking is at times abandoned due to enforcement of social legislation.

Dressing: The access to modern market brought changes in dress material and style. The modern dress materials are available at affordable process; and the increase in their earnings and income and even their increased interaction with 
plains people ushered a complete change in the "dressing style" of Chenchus. Now they no longer are naked just with a loin cloth. They now wear the dress that is being worn by villagers and town people. In other words now mostly one may not find a Chenchu with only a "piece of loin's cloth."

From the foregoing observations it may be evaluated that the changes and developments experienced by Chenchus under reference are within the overall context of the trends of change and development that have been taking place in the country for the past six decades. However, these changes are facilitated and accelerated on account of ITDA's interventions during the last two and half decades.

The close contact and interaction with officials as well as with the neighbouring villagers and impact of schooling, the process of democracy and social justice had gradually led them to greater social awareness in general and in particular the awareness of their rights. In other words, the developmental interventions have led to a slow but steady process of social empowerment of Chenchus. This social process has led the Chenchus to a social transition from folk society to the peasant society life practices.

\section{REFERENCES}

Ayyappan A 1948. A Report on the Socio-Economic Conditions of the Aboriginal Tribes of the Province of Madras. Madras, P. 148.

Bhowmick PK 1992. Chenchus of the Forest and Plateaus. Calcutta: Institute of Social Anthropology.

Thurston E, Rangachari K 1909. Castes and Tribes of Southern India, Vol. II (1909), New Delhi: Cosmo Publications, Reprinted 1975.

Government of India 1990. Report of the Working Group on Tribal Development during Sixth Plan. New Delhi: Ministry of Home Affairs.

Reddy GP 1961. Census of India, Vol. I, Monograph Series, Part V-B (IV). The Chenchus. A Scheduled Tribe of Andhra Pradesh, Office of the Registrar General, Ministry of Home Affairs, India (1961).

Roy Burman BK 1961. Demographic and SocioEconomic Profiles of the Hill Areas of NorthEastern India. Census of India 1961 New Delhi: Office of the Registrar General of India. 